
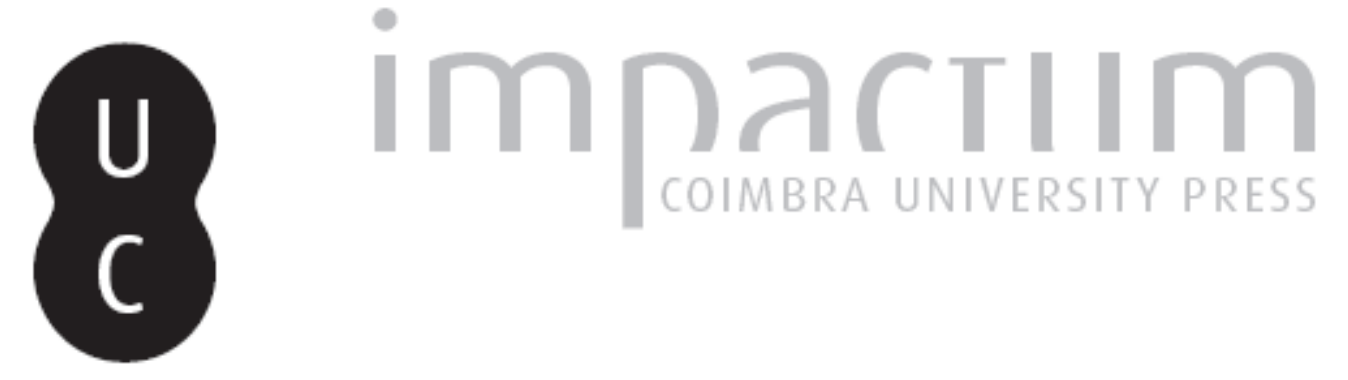

\title{
Iberismo e municipalismo em J. F. Henriques Nogueira
}

\author{
Autor(es): Neto, Vítor
}

Publicado por: Imprensa da Universidade de Coimbra

URL persistente:

URI:http://hdl.handle.net/10316.2/43799

DOI:

DOI:https://doi.org/10.14195/2183-8925_10_39

Accessed : $\quad$ 26-Apr-2023 08:06:17

A navegação consulta e descarregamento dos títulos inseridos nas Bibliotecas Digitais UC Digitalis, UC Pombalina e UC Impactum, pressupõem a aceitação plena e sem reservas dos Termos e Condições de Uso destas Bibliotecas Digitais, disponíveis em https://digitalis.uc.pt/pt-pt/termos.

Conforme exposto nos referidos Termos e Condições de Uso, o descarregamento de títulos de acesso restrito requer uma licença válida de autorização devendo o utilizador aceder ao(s) documento(s) a partir de um endereço de IP da instituição detentora da supramencionada licença.

Ao utilizador é apenas permitido o descarregamento para uso pessoal, pelo que o emprego do(s) título(s) descarregado(s) para outro fim, designadamente comercial, carece de autorização do respetivo autor ou editor da obra.

Na medida em que todas as obras da UC Digitalis se encontram protegidas pelo Código do Direito de Autor e Direitos Conexos e demais legislação aplicável, toda a cópia, parcial ou total, deste documento, nos casos em que é legalmente admitida, deverá conter ou fazer-se acompanhar por este aviso.

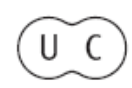


REVISTA DE HISTORIA DAS IDEIAS IO
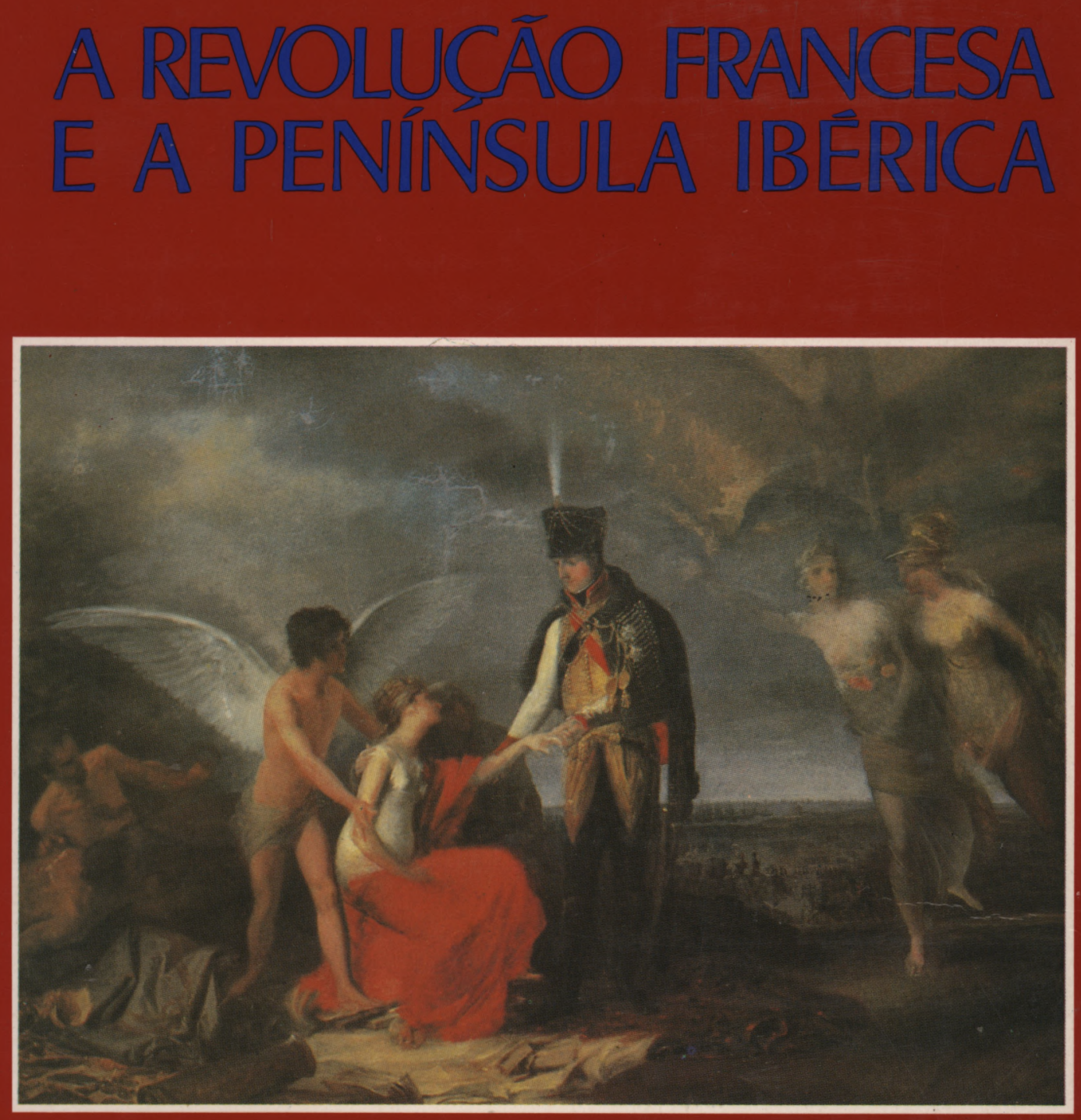

INSTITUTO DE HISTÖRIA E TEORIA DAS IDEIAS FACULDADE DE LETRAS 
VITOR NETO *

\section{IBERISMO E MUNICIPALISMO EM J.F. HENRIQUES NOGUEIRA **}

1. A história das ideias políticas em Portugal foi indiscutivelmente marcada pela obra de Henriques Nogueira que, sendo um intelectual cuja reflexão privilegiava a realidade nacional, não deixou de manifestar uma consciência ecuménica da política. Por isso, a abordagem do seu pensamento tem que incidir, simultaneamente, sobre a sua teoria do estado-nação e a dimensão universalista do seu horizonte cultural. Assim, no contexto do debate político que dividia os intelectuais de meados do século sobre os caminhos a seguir pelo nosso país, o autor de Os Estudos sobre a Reforma em Portugal (1851) rompeu com os pressupostos doutrinários que fundamentavam o liberalismo e construiu um edifício político que, tendo uma inspiração diversa, encontrava a sua base de sustentação nas ideias de República, Democracia, Federalismo e Municipalismo.

Por outro lado, a sua visão da política numa perspectiva europeia esteve na origem das suas teses iberistas. $E$ que, nos inícios da década de 50, esta questão reapareceu no debate ideológico. Todavia, a discussão sobre o iberismo, reacendida, sobretudo, pela obra de D. Sinibaldo de Mas, A Ibéria (1), inseriu-se na problematização da questão das nacionalidades que então ocorria e que encontrara as suas origens na revolução francesa

* Faculdade de Letras da Universidade de Coimbra.

** Este texto serviu de base a uma conferência que realizámos no dia 23 de Janeiro de 1988, em Torres Vedras, inserindo-se na Comemoração dos 130 anos da morte do autor levada a efeito pela Escola Secundária $H$. Nogueira.

(1) Fernando Catroga, Nacionalismo e Ecumenismo. A Questão Ibérica na segunda metade do século XIX, Lisboa, Separata da Revista Cultura, História e Filosofia, vol. IV, s.d., pp. 1-2. 
de 1789. É certo que podemos encontrar alguns assomos ideológicos do nacionalismo em Rousseau, porém foi a crise revolucionária iniciada na última década do século XVIII que esteve na base do nascimento do sentimento nacionalista francês que, posteriormente, ultrapassou as fronteiras da «Grande Nação» $\left(^{2}\right)$. Foi nessa conjuntura que Napoleão, ao pretender impôr às outras nações europeias os princípios da revolução, desencadeou o despertar dos nacionalismos que, no caso específico das Alemanhas, se correlacionava com a emergência da estética e da sensibilidade românticas $\left(^{3}\right)$. Deste modo, pode constatar-se que a luta pela afirmação do princípio das nacionalidades se desenvolveu, depois, (a partir de 1815) e se prolongou ao longo dos séculos XIX e XX.

Foi, aliás, em consequência da expansão dos nacionalismos e dos choques inevitáveis entre as nações com pretensões hegemónicas que a geopolítica europeia encontrou uma configuração recente. Basta lembrar que a unificação italiana apenas foi alcançada em 1870, que a Alemanha de Bismarck se formou entre 1866 e 1870, que a Holanda se separou do Luxemburgo em 1890 e que a Noruega apenas conseguiu a sua independência da Suécia em 1905. E se é certo que a Espanha iniciou a sua unificação com os Reis Católicos, o problema das autonomias dos seus povos jamais seria resolvido $\left({ }^{4}\right)$.

O desenvolvimento e aplicação progressiva do princípio das nacionalidades tinha relações com o surgimento de um certo patriotismo cultural que o romantismo trouxera consigo. Assim, no contexto da primeira metade do século XIX, o teor

(2) Para uma perspectiva histórica da evolução dos nacionalismos desde a sua emergência até aos nossos dias veja-se: Jean-René Suratteau, L'Idée Nationale de la Révolution a nos jours, Paris, P. U. F., 1972 , pp. 59 e ss. Sobre a expansão do nacionalismo, pode ler-se, com proveito: Boyd C. Shafer, Le Nationalisme. Mythe et Realité, Paris, Payot, 1964, pp. 125 e ss. Ou ainda, Hans Khon, Historia del Nacionalismo, México, Fondo de Cultura Económica, 1949, pp. 379 e ss. e Norman Rich, The Age of Nationalism and reform. 1850-1890, London, Weidenfeld and Nicolson, 1970.

(3) Sobre a relação entre a cultura romântica alemã, na sua fase inicial, e o nacionalismo veja-se: Georges Gusdorf, Les Fondements du Savoir romantique, Paris, Payot, pp. 69-104.

(4) Para além disso convém referir que o Reino Unido tal como hoje existe, surgiu com a união dinástica da Inglaterra à Escócia em 1603 e com a independência da República da Irlanda do Sul em 1922. A Grécia moderna constituiu-se em 1829, a Bélgica em 1830, a Bulgária em 1908 e a Jugoslávia, a Checoslováquia, a Hungria, a Roménia e a Polónia actuais nasceram somente em 1919-1920. Vasco Pulido Valente, Tentar Perceber, Lisboa, Imprensa Nacional-Casa da Moeda, s.d., pp. 351-352. 


\section{J. F. Henriques Nogueira}

patriótico e nacionalista do movimento romântico ocupou o lugar do cosmopolitismo da cultura das luzes que tendia a abolir as fronteiras nacionais $\left(^{5}\right)$. Por outro lado, a emergência do estado-nação articulava-se com o desenvolvimento do capitalismo e com a dominação crescente das burguesias que triunfaram sobre o absolutismo nas revoluções liberais. Para além disso, a realidade política da época tem que ser encarada no contexto da relação de forças entre as nações e nos interesses hegemónicos das diversas potências europeias (Inglaterra, França, Rússia, Império Austro-Húngaro e mais tarde a Alemanha). Foi neste quadro que o estado-nação onde já se tinha constituído desempenhou um papel fundamental na destruição das estruturas de Antigo Regime que tinham sobrevivido às revoluções burguesas $\left(^{8}\right)$.

Nesta perspectiva compreende-se que $H$. Nogueira, sendo um ideólogo informado sobre a política europeia, tivesse procurado equacionar a realidade portuguesa à luz das suas relações com as restantes potências do velho continente.

2. A proposta federativa do autor de Torres Vedras retomava o cosmopolitismo Iluminista mas, como representante do romantismo social, teria que atender às especificidades nacionais. Daí que, a seu ver, a solução para o problema da independência do nosso país no contexto geopolítico de meados da centúria pressupusesse, a federação dos povos peninsulares e, internamente, a confederação municipalista. Pode-se, por isso, afirmar que o princípio federativo foi, pela primeira vez, sistematizado em Portugal por H. Nogueira que o inseriu num programa de reforma global do sistema político.

A ideia de federação fazia parte do universo ideológico de muitos intelectuais do 48 francês que, romanticamente, anunciavam o advento da Primavera dos povos. Expresso pela primeira vez por Bernardin de Saint-Pierre, no século XVIII, o federalismo, seria retomado no segundo decénio do século passado por Saint-Simon que pugnava por uma reorganização da sociedade europeia através do recurso à fórmula federativa. Para isso, tornava-se necessário eleger o Parlamento Europeu que, por sua vez, contribuiria para a harmonização dos regimes políticos. Nesta perspectiva, a federação aparecia para o autor

(5) Sobre o carácter universalista da cultura das Luzes veja-se: Georges Gusdorf, Les Principes de la Pensée au siècle des Lumières, Paris, Payot, 1971, pp. 370-375.

(6) Fernando Catroga, ob. cit., pp. 3-4. 
de l'Industrie (1816) como uma das condições do estabelecimento da paz.

Mais tarde, em meados de oitocentos, a ideia foi retomada em França por Victor Hugo que se pronunciou em favor da formação dos Estados-Unidos da Europa $\left({ }^{7}\right)$ e, na década de 60, por Proudhon que combateu o unitarismo defendido em Itália por Mazzini. O projecto do autor Du Principe Fédératif (1862) radicava na articulação entre uma sociedade económica livremente federada (federação agrícola-industrial) com uma democracia política baseada no contratualismo e na capacidade de auto-administração por grupos naturais que constituíam o organismo social (Self-government) $\left(^{8}\right)$.

Foi nessa conjuntura de idealização romântica do federalismo que um grupo de democratas portugueses e espanhóis se reuniu em Paris (1848) e proclamou a federação dos povos peninsulares.

3. O federalismo ibérico de H. Nogueira, é indiscutivelmente, tributário da ideologia humanitária e cosmopolita da época. Porém, a sistematização da ideia e a sua articulação com outros princípios tomou também, como paradigmas os modelos políticos da Suíça e dos Estados Unidos que ele tão bem conhecia através das leituras de Béchart $\left(^{\circ}\right)$ e de Tocqueville. Assim, foi a essa luz que propôs o federalismo como «único caminho conducente a uma verdadeira revivescência das nacionalidades ibéricas» $\left({ }^{10}\right)$. Porém, se Portugal era, desde longa data, uma nação homogénea, a Espanha continuava a debater-se com a questão secular da submissão dos seus povos à centralização política. Por isso, a concretização da sua proposta iberista implicava, como condição prévia, a destruição da hegemonia política de Castela sobre as restantes regiões e a consequente autonomia dos pequenas estados $\left({ }^{11}\right)$. A fragmentação prioritária

(7) Marcel Merle, Pacifisme et Internationalisme, Paris, Armand Colin, 1966, pp. 217-230.

(8) Para um conhecimento sistematizado do pensamento de Proudhon, leia-se o excelente estudo de Jean Bancal, Proudhon. Pluralisme et autogestion, Paris, Aubier Montaigne, 1970.

( $)$ Béchart foi um autor que se debruçou sobre as organizações administrativas. $\mathrm{H}$. Nogueira conhecia a sua obra, De L'administration de la France et Lois Municipales de la Suisse et des Etats-Unis e pôde, assim, beneficiar das informaçōes sobre esta matéria nelas contidas.

(10) Fernando Catroga, Os Inícios do Positivismo em Portugal, separata da Revista de História das Ideias, vol. 1, Coimbra, 1977, p. 44.

(11) Idem, Nacionalismo e Ecumenismo. A Questão Ibérica na segunda metade do século XIX, separata da Revista Cultura, Historia e Filosofia, vol. IV, s.d., p. 41. 


\section{J. F. Henriques Nogueira}

da Espanha permitia a Portugal estabelecer um contrato político com a Galiza, Astúrias, Biscaia, Navarra, Catalunha, Aragão, Valência, Múrcia, Granada, Andaluzia, Estremadura, Castela-a-Nova, Castela-a-Velha e Leão. Formava-se, em consequência, uma grande nação peninsular - «a Ibéria dos povos» - condição fundamental, a seu ver, para alcançar uma verdadeira independência nacional ${ }^{(2)}$.

Para legitimar a sua proposta $\mathrm{H}$. Nogueira recorria a uma argumentação historicista ao procurar demonstrar, nessa perspectiva, que após a época áurea das descobertas, Portugal entrara numa longa agonia decadentista agravada pelo trauma provocado pela perda do Brasil. Daí que a regeneração da pátria passasse, entre outros aspectos, pela recuperação da sua dignidade no contexto político internacional $\left({ }^{13}\right)$. Este facto exigia, porém a libertação do país da tutela política inglesa que, a coberto da roupagem da velha aliança, influenciava por vezes de maneira determinante, a sua evolução política. Por outro lado, a opção federativa do ideólogo não era incompatível com a ideia de pátria, valor que fazia parte da sua mundividência política. $\mathrm{O}$ contrato federativo seria - em consequência do que foi dito - uma garantia da liberdade das partes que constituíam a totalidade social. Isso implicava a rejeição da alienação da soberania e da individualidade de cada uma delas. Assim, o todo nacional associado a outros povos surgia como uma das condições da liberdade dos indivíduos e do princípio da soberania popular.

Por tudo isto verifica-se que o autor, ao debruçar-se sobre uma conjuntura internacional caracterizada pela expansão dos nacionalismos, se mostrava adepto da formação de grandes conjuntos políticos pois, só por essa via, era possível restabelecer os equilíbrios geopolíticos. Em 1848, como se sabe, a Europa foi sacudida por um movimento revolucionário que suscitou uma onda de esperança nos patriotas de vários países empenhados na libertação dos seus povos em relação ao predomínio político de algumas potências. Porém, após o desabrochamento

(12) J. F. Henriques Nogueira, Estudos sobre a Reforma em Portugal, in Obra Completa, ed. organizada por António Carlos Leal da Silva, Tomo I, Lisboa, Imprensa Nacional-Casa da Moeda, 1976, p. 163.

(13) Sobre o carácter subalterno do nosso país no contexto das relações políticas internacionais afirmava o nosso autor: «Portugal, desde a perda do Brasil, figura nominalmente na lista das nacões, mas em realidade não passa, não tem passado, não pode passar, de ser um satélite de astro ou astros maiores. Umas vezes a Inglaterra o atrai à sua órbita, outras a França, e não raras a vizinha Espanha». J. F. Henriques Nogueira, $O$ Iberismo e os seus adversários $I V$, in $O$ Progresso, 17-3-1855. 
insurreccional, assistiu-se ao refluxo dos movimentos sociais e políticos e, em consequência disso, a resolução da «questão italiana» e da "questão alemã» ficou adiada só encontrando uma solução unificadora cerca de dois decénios mais tarde. Por outro lado, se a Suíça, se transformara, nessa conjuntura, num estado federativo pluri-racial, plurilinguístico e pluriconfessional, os povos magiares e eslavos, apesar de revoltados, tiveram que continuar a suportar o jugo do Império dos Habsbourg ${ }^{\left({ }^{14}\right)}$. H. Nogueira conhecia esta realidade e, nessa medida, é compreensível a mitificação que fazia dos «heróis» que, no decurso da crise revolucionária, tinham lutado pela autonomia dos seus povos.

Isso acontecia em relação a Kossuth, líder da revolução húngara desencadeada contra o Império austríaco, a Mazzini, «profeta da unidade italiana» a Manin, eleito presidente da república de Veneza no curto período em que a cidade se libertou do domínio da Austria e a Victor Hugo que aderira à revolução democrática e social de 1848 e celebrava, literariamente, a humanidade e a fraternidade ${ }^{15}$ ). No que se refere ao autor dos Miseráveis, a dimensão ecuménica do seu pensar levava-o a desejar o restabelecimento da solidariedade entre os povos como condição para a obtenção da paz.

$\mathrm{O}$ autor de $O s$ Estudos, ao reflectir sobre a realidade política europeia admitia a federação como solução provável para a independência dos povos italianos, alemães, eslavos e magiares. Tratava-se assim de reformular o xadrez político do continente através da aplicação do princípio das nacionalidades - que significava a libertação das pequenas pátrias da dominação política tradicional das potências mais poderosas. Ou por outras palavras, o federalismo europeu pressupunha o fim da hegemonia política da Inglaterra, França, Rússia e Austria.

Em consequência disso, deviam afirmar-se, politicamente, novas nações: a Penísula Ibérica, a Itália, a Alemanha, a Polónia e a Hungria. Por outro lado, a dimensão ecuménica do seu ideário, a que temos feito referência, levava-o a desejar que

(14) Jean-René Suratteau, ob. cit., pp. 118-132. Sobre o movimento das nacionalidades a partir de 1860 veja-se: P. Benarts e outros, Nationalité et Nationalisme (1860-1878), Paris, P.U.F., 1968. Sobre os conceitos de pátria e nação pode ler-se: Jean-Yves Guiomar, L'Idéologie National, Paris, Editions Champ Libre, 1974.

(15) Para além destas personalidades outros intelectuais, ou políticos, desempenharam uma função mítica na consciência de $\mathrm{H}$. Nogueira; ex: Ledru-Rollin, Lamartine, Raspail, General Pepe, R. Blum, Cobden, etc. Este facto, pode ser comprovado com a leitura dos pequenos artigos que sobre eles escreveu nos Almanaques Democráticos publicados a partir de 1852 . 
a humanidade - que se transformara no objecto de um verdadeiro culto para o romantismo social - encontrasse a harmonia na aplicação do princípio federativo. Para além disso, estabelecido o ideal evangélico da fraternidade entre os povos e a "protecção recíproca» estavam criadas as condições para o alargamento da paz a todo o "género humano» ${ }^{(16)}$. O pacifismo, também perfilhado por $H$. Nogueira, reflectia o espírito da época pois, como se pode verificar, era um dos temas debatidos com mais frequência em meados do século XIX, altura em que se re-equacionavam as relações políticas internacionais. No entanto, a origem desta aspiracão encontra-se em Bernardin de Saint-Pierre que, no século XVIII, tinha elaborado um projecto de paz perpétua $\left({ }^{17}\right)$. A ideia de paz que tanto significado viria a adquirir, posteriormente, teve o seu próprio percurso e vêmo-la ser retomada, entre outros, por Saint-Simon após a queda do Império de Napoleão Bonaparte $\left(^{18}\right)$.

4. Ao nível da instância económica, a realização do progresso material necessário ao arranque definitivo do capitalismo era o problema fundamental que se colocava às élites do país. E se essa questão ocupava o espírito de iberistas e anti-iberistas o nosso autor defendia a compatibilização entre a federação política peninsular com uma estrutura económica de tipo livre-cambista $\left({ }^{19}\right)$. O novo e amplo espaço económico que resultava da formacão da Ibéria abriria à indústria portuguesa «um mercado de 17 milhões de habitantes». Isso pressupunha a extinção do sistema alfandegário tradicional e a institucionalização de um sistema pautal uniforme inspirado no zolverein alemão. Sendo assim, a realização da ideia de progresso material estava dependente da formação prévia do federalismo ibérico e, nessa medida, Nogueira concluía, optimista que «a união pode ser para nós um novo Brasil».

5. Iniciado ainda na década de 40, em Espanha, o debate sobre o iberismo foi depois alargado a Portugal por volta de 1852

(16) J. H. Henriques Nogueira, Estudos sobre a Reforma em Portugal, in Obra Completa, T. I, Ed. organizada por António Carlos Leal da Silva, Lisboa, Imprensa Nacional-Casa da Moeda, 1976, pp. 162-163.

(17) Théodore Ruyssen, Les Sources doctrinales de l'Internationalisme, T. 2, Paris, P.U.F., 1958, pp. 580-588.

(18) Para o conhecimento do ideário Saint-Simoniano veja-se, por exempla: Pierre Ansart, Marx et l'Anarchisme, Paris, P.U.F., 1969.

(19) Sobre as relações entre o iberismo e a economia livre-cambista inseridas num estudo mais geral sobre a "questão ibérica» veja-se: Manuela Mascarenhas, A Questão Ibérica. 1850-1870, Braga, Separata da Kevista Bracara Augusta, 1980, pp. 15-18. 
país no qual a ideia de federação foi usada como arma ideológica com fins diversos. $O$ federalismo de $H$. Nogueira distanciava-o da soluçãa unitarista apresentada na Ibéria por D. Sinibaldo de Mas e reassumida, entre nós, por autores como Latino Coelho. Por outro lado, o nosso ideólogo tinha também que fazer frente aos nacionalismos liberal $\left({ }^{20}\right)$ e legitimista que nasceram ou recrudesceram nessa conjuntura. E claro que as teses iberistas de carácter unitário têm que ser vistas também no contexto das lutas travadas entre as potências europeias pela hegemonia imperialista. Foi nesse quadro que o projecto desta corrente iberista tinha como objectivo superar o estado de subalternidade e fraqueza, no contexto político internacional, de países periféricos como o eram Portugal e Espanha. Nesta perspectiva, se a regeneração peninsular exigia uma posição anti-imperialista não deixava também de implicar a emergência de um sentimento imperialista traduzido no desejo de reconquista do estatuto de potência colonial ( $\left.{ }^{21}\right)$. Porém, o republicanismo democrático e descentralizador do autor de Os Estudos impedia que ele aceitasse a unificação das coroas dos dois países e a criação de uma monarquia parlamentar como cúpula do edifício político peninsular.

Os legitimistas recorreram à imprensa conservadora $-A$ Nação, a Imprensa e lei e o Portugal - para esgrimirem contra os propósitos federativos de H. Nogueira fazendo-o a partir de um nacionalismo exacerbado. Este grupo social e político nunca aceitara a ordem liberal saída da guerra civil de 1832-1834 e, em consequência, continuava a pugnar pela restauração do Antigo Regime. Esta atitude decorria de princípios doutrinais à luz dos quais se recusava a concepção nominalista da sociedade liberal, assente como se sabe, na atomização do indivíduo e na ideia de soberania nacional. Em contrapartida, os miguelistas, viam nos princípios jusdivinistas correlacionados com os direitos históricos a legitimação de uma ordem social baseada na corporação, na província e na igreja. Tratava-se, para este sector social, sempre presente no debate ideológico

(20) Ao analisar os efeitos do iberismo na emergência do nacionalismo liberal afirma Fernando Catroga «se o iberismo não conseguiu os apoios sociais e políticos necessários à sua viabilização, é todavia indiscutível que provocou um efeito contrário aos seus propósitos ao desencadear uma intensa campanha anti-ibérica e pró-nacionalista. E esta, por sua vez, foi um factor ideológico importante para a transformação do patriotismo em nacionalismo, isto é, para a nacionalização de uma sociedade liberal tida por estrangeirada pela propaganda reaccionária». Fernando Catroga, ob. cit., p. 13.

(21) Idem, ibidem, p. 10. 


\section{J. F. Henriques Nogueira}

de todo o século XIX e parte do XX, de conciliar o catolicismo ultramontano com o rei ${ }^{22}$ ). E assim, é à luz desta ideologia, que se compreende a posição do Padre Rodrigo de Almeida que, nas colunas de $A$ Nação, publicou alguns artigos anti-iberistas intitulados: «Isso nunca». Na polémica então desencadeada o autor de $O$ Municipio no século XIX respondeu às acusações do seu adversário no jornal $O$ Progresso, de que era um dos redactores, retomando as ideias federalistas já expendidas nos Estudos e nos Almanaques Democráticos de 1853 e demonstrava, simultaneamente, que o federalismo não era incompatível com o patriotismo.

6. As leituras que H. Nogueira fez dos ideólogos europeus do seu tempo - Louis Blanc, Tocqueville, Raspail, Lamartine, Victor Hugo, Fourier, Mazzini, etc. - e a viagem que realizou em 1853 a Inglaterra, Alemanha, Bélgica, França e Espanha rasgaram os seus horizontes políticos e estiveram certamente na origem do ecumenismo que assumia $\left({ }^{23}\right)$.

Foi em consequência disso, que o autor elaborou a sua proposta de institucionalização de uma federação internacional, sob a forma de uma República Universal, como processo de harmonizar as relações entre todos os povos. Esta idealização era, porém mediada, como ficou exposto, pela solução prioritária da questão peninsular. No entanto a federação, no plano externo, deveria conciliar-se, como já foi sublinhado, com uma estrutura política interna corporizada na confederação de municípios. De facto, esta instituição por ele idealizada surgia como uma unidade político-administrativa fundamental para a emergência e consolidação do estado-nação. Nesta óptica pensamos que o nosso autor foi um dos intelectuais que, na conjuntura política de meados do século, melhor compreendeu a necessidade da formação de uma estrutura política que estivesse omnipresente em todo o território nacional. Todavia a ideia de nação já existia anteriormente e, à «nação territorial» correspondia uma «nação cultural». E que se assistiu em Portugal ao surgimento precoce de algumas estruturas políticas conducentes à edificação do estado-nação. A existência de uma unidade de território, língua, religião e as similitudes étnicas foram elementos importantes para a sua constituição. Por outro lado, o absolutismo pombalino desempenhou um papel importante no caminho da cons-

(22) Idem, ibidem, p. 17.

(23) Após este contacto com a Europa H. Nogueira publicou nalguns números do Arquivo Pitoresco as suas «Recordações de Viagem». 
trução de um estado de âmbito nacional não só pela centralização do poder político que então se processou, mas também pelo desenvolvimento do aparelho burocrático-administrativo estadual. No entanto, apesar do país ter chegado a meados do século passado com muitos problemas já resolvidos que preocupavam outros povos (fixação de fronteiras, unidade de língua, de religião e de poder político) era ainda necessário destruir muitos particularismos de Antigo Regime que obstaculavam a uniformização das estruturas político-ideológicas e do espaço económico $\left({ }^{24}\right)$. Nesta perspectiva, o liberalismo triunfante em 1834 foi apenas, como reconheceu $H$. Nogueira, um sistema político transitório. A ruptura dos inícios da década de 30 e as reformas económicas e sociais consequentes (venda dos bens nacionais e extinção das ordens religiosas) foram factos importantes para a consolidação do estado-nação. Mas, as revoltas da Maria da Fonte (1846) e da Patuleia (1847) desencadeadas no Consulado de Costa Cabral são a demonstração inequívoca de que a sociedade civil ainda resistia à implementação das estruturas político-administrativas globais $\left({ }^{25}\right)$.

O liberalismo era, como se sabe, um sistema político representativo que encontrava a sua fundamentação no princípio da soberania nacional. A configuração jurídica do modelo encontra-se nas três Constituições do século XIX (Constituição Vintista, Carta Constitucional de 1826 e Constituição de 1838). No entanto, a divisão social entre cidadãos activos e cidadãos passivos justificada doutrinariamente e, em primeiro lugar, por J. Locke no Ensaio sobre o Governo Civil (1689) tinha, como consequência, o afastamento da participação no sufrágio da maioria da população. Por isso, com o liberalismo, a igualdade de direitos políticos era ainda uma quimera. A este facto acrescentava-se a doutrina jusdivinista que sobrevivera com a Carta Constitucional de 1826 outorgada à nação por D. Pedro IV. Por outro lado, o desenvolvimento do capitalismo processou-se, entre nós, a um ritmo muito lento o que permitiu a permanência de muitas estruturas económicas de Antigo Regime (ex.: o morgadio só seria definitivamente abolido em 1863). No plano das ideologias, e não obstante o esforço de intelectuais como Herculano e Garrett para adequarem esta instância à nova ordem política, a «família» católica ultramontana conti-

(24) Fernando Catroga, Nacionalismo e Ecumenismo...., pp. 13-14.

(25) Sobre a política centralizadora levada a cabo por Costa Cabral e as insurreições populares que ela provocou veja-se: $M$. Villaverde Cabral, $O$ desenvolvimento do Capitalismo em Portugal no século XIX, Porto, A Regra do Jogo, 1976, pp. 123-158. 


\section{J. F. Henriques Nogueira}

nuava a difundir os valores de Antigo Regime. A posição destes católicos abriu, aliás, uma clivagem com aqueles liberais que, sem deixarem de assumir semelhante posição religiosa, se identificavam também com o novo sistema político e não aceitavam a política anti-liberal e anti-racionalista do Vaticano (especialmente com o Papa Pio IX). Pelo que foi dito, compreende-se que as relações de fidelidade à monarquia se mantivessem, ou até que a subordinação à nobreza provincial e ao clero tradicional continuassem a pautar as atitudes de muitos grupos sociais. Daí que o estado-nação não fosse ainda sentido, enquanto símbolo, em algumas regiões do país. a proposta política de $\mathrm{H}$. Nogueira, ao encontrar a sua fundamentação em novos princípios (democráticos), representava uma superação do liberalismo e objectivava a construção de um estado cujas regras de funcionamento tendiam a unificar, embora na diversidade regional, a nação.

7. No edifício político que a autor construiu a monarquia era substituída pela república e a democracia erguia-se a partir do recurso ao sufrágio universal só possível com a igualdade da cidadania. Por isso, parece-nos indubitável a existência de um fundo ideológico rousseauniano no seu projecto político. Sendo assim, também $H$. Nogueira era tributário das concepções atomistas da sociedade e das teorias contratualistas vindas do jusnaturalismo.

A um nível mais concreto constata-se que a generalização do voto exigia a participação «ilustrada» na vida política. Desse facto, decorria a necessidade de transmitir capacidade eleitoral aos cidadãos que lhes permitisse a liberdade de escolha democrática $\left.{ }^{28}\right)$. Isto, porém, só era alcançável através do acesso universal a um sistema de ensino laico. Nesta óptica, compreende-se o empenhamento de $\mathrm{H}$. Nogueira na criação de um novo plano de instrução que, no dizer do Prof. Luís de Albuquerque, «é o mais positivo e completo trabalho que até então se tinha publicado sobre o assunto na língua portuguesa» $\left({ }^{27}\right)$.

$O$ autor de Os Estudos sabia que a democracia não era possível sem a transformação do homem comum em cidadão esclarecido e, para a fundação do novo sistema político defendia que fossem facultados à população em geral, os meios que lhe

(26) J. F. H. Nogueira, ob. cit., pp. 25-36.

(27) Sobre o plano de reforma de ensino do nosso autor e as influências pedagógicas que nele exerceu Carnot veja-se: Luis de Albuquerque, Notas para a história do ensino de Portugal, Coimbra, Textos Vértice, p. 159 e ss. 
permitisse o acesso aos conhecimentos. Daí a importância da pedagogia no projecto do autor e a consciência de que só através dela era possível libertar as classes populares do estado de ignorância quase generalizada em que se encontravam e iniciar um processo de mudança progressiva das mentalidades.

A instrução pública facultada, especialmente, pelas escolas municipais encontrava o seu complemento na imprensa que, para o efeito, seria revitalizada. Esta teria, por seu lado, um papel essencial na criação de uma opinião pública necessária à sustentação ideológica do regime democrático.

Sob o ponto de vista religioso, $H$. Nogueira encarnava os valores do cristianismo social que caracterizavam a espiritualidade dos homens do 48 francês $\left({ }^{28}\right)$. Como se sabe, o romantismo trouxe consigo um renascimento da religiosidade que se caldeou com as aspirações democráticas dos jovens inconformistas de meados do século. Daí que a ideologia veiculada pelos republicanos de tendência socializante tivesse um fundo evangélico expresso em ideias como o idealismo, o optimismo e o messianismo. Foi neste quadro de ressurgência religiosa que o autor procurou reactualizar os valores do cristianismo primitivo (fraternidade, igualdade, tolerância, caridade, etc.) e propor, a essa luz, a renovação do Catolicismo. Por outro lado, a pacificação das relações entre o estado e a igreja era importante para o estabelecimento da ordem na sociedade e para a moralização do cidadão da República. Este objectivo encontra, aliás confirmação nas suas próprias palavras: «Fazemos votos por que a filosofia, a religião e a política se harmonizem e por que o acórdão desta trindade seja levado pela conviç̧ão aos mais remotos confins da terra» ${ }^{(29)}$.

8. A estruturação do estado-nação implicava, a nível central, a divisão tripartida do poder e a instituição de um Parlamento unicameral, garante das liberdades individuais. No entanto, os corpos intermédios do estado - os municípios - desempenhariam uma função insubstituível na criação das uniformidades políticas da nação. Federados entre si teriam em relação à sociedade, no seu conjunto, uma função congregadora e unificadora. Com a nova estruturação do estado o poder dis-

(28) Para o estudo deste aspecto leia-se: Maria Manuela Tavares Ribeiro, "O Cristianismo social de 1848", Revista de História das Ideias, vol. 9, Coimbra, 1987, pp. 481-494. Um bom estudo sobre a religiosidade romântica encontra-se em Georges Gusdorf, Du Néant á Dieu dans le Savoir Romantique, Paris, Payot, 1983, pp. 89 e ss.

(29) J. F. Henriques Nogueira, ob. cit., pp. 125-126. 


\section{J. F. Henriques Nogueira}

tribuía-se pelos municípios autónomos e às instâncias centrais - governo e parlamento - não mais cabia que coordenar a política geral do país.

As ideias municipalistas de $\mathrm{H}$. Nogueira que o levavam a fazer a apologia da instituição e a ver nela a «unidade fundamental do estado», encontraram, em parte, a sua inspiração em Alexandre Herculano, seu «mestre e amigo». O modelo liberal ideado pelo autor de Os Opúsculos, foi concebido a partir de uma teoria do estado baseada na descentralização do poder pois, só através dela, era possível estabelecer o governo do país pelo país. No entanto, se é certo que Herculano deixou os lineamentos, ainda que dispersos, do novo poder local não criou um modelo municipalista como o que a instituição viria a ter no programa político do seu discípulo $\left({ }^{30}\right)$. Historiador da Idade Média, o solitário de Vale de Lobos, reconstruiu os concelhos desse período dando relevância à autonomia das magistraturas, à vida política local e à resistência à centralização política. Sendo assim, o autor de $O$ Município no século XIX que, enquanto romântico, privilegiava a Idade Média na leitura historicista que fazia do devir social pôde tomar como paradigma a organização concelhia de Herculano. Deste modo, foi a partir desse pano de fundo que $\mathrm{H}$. Nogueira definiu «o arquétipo do concelho moderno». Assim, através do município democratizado pelo sufrágio universal e regulado por uma legislação comum a todo o território era possível estruturar, politicamente, o todo nacional confederando as suas partes constituintes.

Se na época em que viveu o ideólogo se viu confrontado com a centralização política liberal, ao nível doutrinário estava perante duas concepções administrativas radicalmente opostas. Ou por outras palavras, enquanto alguns «publicistas» preconizavam o estabelecimento de um poder político concentracionário inspirando-se para o efeito nos modelos espanhol, francês e, em parte, italiano outros defendiam a descentralização por considerarem este sistema administrativo mais eficaz para a governação local $\left({ }^{31}\right)$. Foi neste quadro de divergências ideológicas sobre a forma de estruturar o estado que o nosso autor pôde definir as características do novo concelho. Para tal extraiu ilações da experiência política mais descentralizadora levada a cabo pelo liberalismo democratizante (Vintismo e Setembris-

(30) Vitor Neto, «Herculano: Política e Sociedade», Revista de História das Ideias, n. 7, Coimbra, 1985, p. 666.

(31) J. F. Henriques Nogueira, $O$ Município no século $X I X$, in Obras Completas, ed. organizada por António Carlos Leal da Silva, T. 2, Lisboa, 1979, Imprensa Nacional-Casa da Moeda, pp. 13-14. 
mo) e tomou como referência os modelos anglo-saxónicos e suíço tradicionalmente descentralizadores). Assim, as experiências políticas por um lado e as influências ideológicas por outro, estiveram na base da sua proposta municipalista que, ao concretizar-se procurava conciliar os benefícios da centralização com as vantagens que a descentralização também comportava. E que, enquanto a primeira dava a uniformidade política necessária à consolidação do estado-nação $\left({ }^{32}\right)$, a segunda era geradora da individualidade e autonomia locais. $\mathrm{O}$ autor sabia, aliás, que a configuração definitiva do estado-nação só era possível desde que fossem estabelecidas a unidade das leis, uma tributação fiscal extensiva a todo o território e a todas as classes sociais, a igualdade de pesos e medidas em todas as regiões e a criação de uma estrutura económica sem a existência de barreiras alfandegárias interiores ${ }^{(33}$ ).

Iguais em direitos e em deveres os cidadãos locais encontrariam nas instituições municipais uma multiplicidade de apoios - económicos, educacionais, assistenciais, jurídicos, etc. - que objectivamente contribuíam para a criação de condições necessárias à obtenção da felicidade pelas populações. Para além disso o município, enquanto estrutura intermédia do poder de estado, desempenhava uma função pedagógica conducente à interiorização pelo habitante da sua área da ideia de nação. $€$ que a racionalização do aparelho de estado, no seu conjunto, implicava a criação de uma administração local assente numa base geográfica para que as instituições estivessem ao alcance fácil do habitante comum. Nesta perspectiva, o município teria como finalidade «conciliar, promover e dirigir os interesses de todos os cidadãos que habitarem o seu território» ${ }^{(34}$. Estes, ao desenvolverem a sua vida social e as suas relações na área municipal, passariam a ver nela uma pequena pátria inserida numa pátria de maiores dimensões: a nação portuguesa.

Numa sociedade plenamente democratizada e formada por cidadãos livres e iguais perante a lei as magistraturas locais teriam que encontrar a sua legitimidade no sufrágio universal usado pelas populações concelhias. Ao nível da concretização do poder as instâncias superiores do estado articulavam-se com o poder local através de um «conselho administrativo» formado por representantes do poder central. Assim, a organização ver-

(32) Idem, Estudos sobre a Reforma em Portugal, in Obra Completa, T. 1, ed. organizada por António Carlos Leal da Silva, Lisboa, Imprensa Nacional-Casa da Moeda, 1976, p. 136.

(33) Idem ibidem, pp. 45-46.

(34) Idem, O Município no século XIX, p. 16. 


\section{J. F. Henriques Nogueira}

tical do poder, desde a base (freguesia) até à cúpula (capital) era mediada pelas estruturas municipais. Nesta perspectiva os municípios transformavam-se nos corpos essenciais do estado-nação, uma vez que, seria através deles que o poder se distribuía pelas regiões. Unidade político-administrativa fundamental a instituição de poder local transformava-se num pequeno estado que, ao aplicar a lei geral, contribuía para o desenvolvimento da unidade nacional.

Por outro lado a cidadania política, indispensável à vida democrática local e nacional, passava também pela independência económica das populações. Por isso, a extinção do proletariado rural e industrial era um dos aspectos essenciais do programa social de $\mathrm{H}$. Nogueira. Tal facto tornava-se possível através da universalização da propriedade um pouco à semelhança do que acontecia no projecto de A. Herculano $\left({ }^{35}\right)$. O município, que era também uma unidade económica (agricultura, indústria, comércio) e uma unidade moral (relações de vizinhança e parentesco), encontrava a sua base sociológica nos pequenos e médios proprietários agrícolas e industriais associados entre si (socialização das relações humanas) $\left({ }^{36}\right)$.

9. Não foi propósito desta exposição parcelar do ideário do autor de Torres Vedras, fornecer uma perspectiva globalizante do seu pensamento, o que não seria, naturalmente, possível numa comunicação desta natureza. Mas, se o fizessemos teríamos, certamente, que relevar o carácter utópico da sua proposta configurado na idealização de uma Cidade na qual era possível realizar a perfectibilidade individual e a felicidade colectiva. No entanto, cremos que pela compreensão que H. Nogueira revelou da necessidade da emergência definitiva do

(35) Tal como em A. Herculano a ideologia agriculturalista de H. Nogueira levava-o a desejar o desenvolvimento económico, para o nosso país, a partir, de uma agricultura sustentada por pequenos e médios proprietários. No entanto, se as ideias do autor de Os Opúsculos coincidiam com as do seu discípulo no objectivo de eliminar o proletariado através da generalização da propriedade, o recurso à enfiteuse, adaptada ao século XIX, distanciava-o de H. Nogueira, defensor da propriedade alodial.

(36) A proposta social do autor baseava-se na criação de um associacionismo livre conciliado com o princípio do individualismo. A associação, que para os socialistas românticos era a fórmula mágica para a resolução da questão social foi reassumida em Portugal, entre outros, por $H$. Nogueira que via nela o meio de regenerar física e moralmente o operariado. Parece-nos que o associacionismo de Fourier influenciou de maneira significativa, o nosso ideólogo, neste aspecto. 
estado-nação e pela solução federativa que propunha para regular as relações políticas peninsulares e universais, a sua obra continua a ser um referente essencial para todos aqueles que procuram entender a política do presente à luz de uma visão historicista do devir social. 